\title{
Dengka Pada dalam Upacara Adat Je'ne-Je'ne Sappara di Desa Balangloe Kecamatan Taroang Kabupaten Jeneponto
}

\author{
Hajar \\ Universitas Negeri Makassar \\ hajarlambu@gmail.com
}

\begin{abstract}
Abstrak
Penelitian ini membahas tarian tradisional Dengka Pada pada upacara adat Jene-jene Sappara di masyarakat Jeneponto Sulawesi Selatan yang merupakan pewarisan budaya secara turun-temurun. Menurut masyarakat Jeneponto, tarian ini sudah ada sejak masyarakat masih menganut kepercayaan (animisme/dinamisme). Tarian ini menggambarkan kegembiraan masyarakat Jeneponto setelah berhasil melakukan panen di sawah. Penelitian ini menggunakan metode penelitian kualitatif dengan pendekatan etnografi. Data yang terkumpul dianalisis dengan cara reduksi data, pengelompokan, dan validitas data. Hasil analisis data menunjukkan bahwa tari Dengka Pada menggambarkan suatu kegembiraan masyarakat Jeneponto yang diwujudkan dalam gerakan tari, baik gerakan tangan dan kaki serta pola lantai para penari baik secara berhadapan maupun dalam bentuk lingkaran. Pelaksanaan tari Dengka Pada ini dilakukan baik pada waktu malam hari maupun di siang hari di tempat keramaian seperti lapangan.
\end{abstract}

Kata kunci: seni tari, kualitatif, pewarisan, dengka pada, jeneponto

\begin{abstract}
This study discusses the traditional dance of South Sulawesi which is the hereditary cultural heritage. This dance is called Dengka Pada which is staged at the traditional ceremony of Jene-jene Sappara. According to the Jeneponto community, this dance has been around since still adheres to the religion of belief (animism/dynamism). This dance reviews the excitement of the community. This research uses qualitative research method with ethnography approach. The collected data is analyzed by data reduction, grouping and validity data. The result of data analysis shows that Dengka Dance In the happiness situation where society Jeneponto have succeeded in harvesting in paddy field. This excitement is manifested in dance movements, both hand and foot movements and the position of the dancer either intact or in a circle. Implementation of Dengka dance This is done both at night and during the day in a crowded place. Dengka Dance In this there is and developed in the environment of the people of South Sulawesi, especially the Jeneponto Community and developed from generation to generation for the supporters.
\end{abstract}

Keywords: dance, qualitative, inheritance, dengka pada, jeneponto 


\section{Pendahuluan}

Indonesia dikenal sebagai negara yang memiliki keanekaragaman seni. Warisan budaya nasional merupakan perwujudan cipta, karya, dan karsa bangsa Indonesia sepanjang masa. Warisan budaya tradisional tersebut merupakan bagian dari sistem nilai dan ide dasar yang pernah dihayati oleh bangsa Indonesia. Hal ini berarti warisan budaya pada hakikatnya merupakan kekayaan budaya yang perlu dipelajari dan dilestarikan.

Keragaman budaya bangsa Indonesia ini pada hakikatnya adalah satu, sedangkan corak ragam budaya yang ada menggambarkan kekayaan budaya bangsa yang menjadi moral dan landasan pengembangan budaya bangsa seluruhnya, seperti yang tercantum dalam Propernas (2004: 38). Kebijakan pembangunan yaitu:

Pembangunan nasional dicurahkan untuk memberikan wawasan budaya dan makna pada pembangunan nasional segenap dimensi kehidupan masyarakat, berbangsa, dan bernegara. Kebudayaan nasional ditujukan untuk meningkatkan harkat dan martabat manusia, jatidiri dan kepribadian bangsa, mempertebal rasa harga seni, kebanggaan nasional bangsa sebagai pencerminan pembangunan yang berbudaya dalam mengembangkan kebudayaan bangsa perlu ditumbuhkan kemampuan untuk mengembangkan nilai budaya daerah yang luhur dan beradab serta mencapai nilai budaya asing yang positif untuk memperkaya budaya nasional.

Kesenian sebagai bagian integral yang tak terpisah dari kebudayaan secara keseluruhan, memerlukan berbagai upaya serius untuk melestarikannya, dalam arti menumbuhkembangkan pada masyarakat tersebut. Upaya untuk melestarikannya harus didukung seluruh komponen, baik pemerintah, masyarakat, maupun perguruan tinggi.

Sebagai salah satu institusi ilmiah, Universitas Negeri Makassar (UNM) melalui jurusan Pendidikan dan Seni Drama, Tari dan Musik (Sendratasik) yang merupakan pemegang peran utama dalam hal pengembangan kesenian di daerah dengan latar belakang akademis, dapat dipertanggungjawabkan secara intelektual. Keterlibatan perguruan tinggi menjadi penting karena berlatar belakang kepakaran kaum intelektual di bidang kesenian, karya seni dapat dilestarikan. Mengingat tujuan dan latar belakang fungsi, bentuk, ragam asli dan bentuk pengembangan tari tradisional yang selalu ditampilkan dalam pesta adat.

Salah satu kebudayaan daerah di Sulawesi Selatan adalah upacara pesta adat, dalam hal ini upacara adat Je'ne-Je'ne Sappara di Desa Balangloe, Kecamatan Taroang Kabupaen Jeneponto. Budaya pesta adat ini saat sekarang hampir punah dan kurang dipahami makna yang terkandung di dalamnya. Walaupun kita ketahui bahwa sebagian daerah di Indonesia melaksanakan upacara semacam ini.

Untuk itu, penulis ingin terjun langsung ke lapangan untuk menggali informasi dan mengembangkan kebudayaan Dengka Pada dalam upacara Je'ne-Je'ne Sappara di Desa Balangloe Kecamatan Taroang Kabuapaten Jeneponto. 


\section{Metode Penelitian}

\section{A. Pendekatan Penelitian}

Pendekatan dalam penelitian ini menggunakan pendekatan kualitatif. Di sini dimaksudkan terutama dalam arti bahwa cara-cara pengumpulan data, pengolahan dan pengorganisasian data dilakukan berdasarkan prosedur yang lebih condong pada pendekatan kualitatif. Oleh karena penelitian/kajian ini bersifat empiris, maka prosedur pengumpulan data, pengolahan data, pengorganisasiannya akan dilakukan dengan metode yang bersifat etnografi, yaitu pendeskripsian terhadap observasi.

\section{B. Lokasi Penelitian}

Mengingat luasnya wilayah Makassar dan sesuai dengan judul penelitian yaitu Dengka Pada dalam upacara Je'ne-Je'ne Sappara, maka untuk memperoleh data dan informasi dalam rangka menjawab permasalahan tersebut dan juga sesuai dengan ketentuan lokasi yang telah ditentukan, maka yang menjadi sasaran lokasi penelitian ini adalah Desa Balangloe Kecamatan Taroang Kabupaten Jeneponto.

\section{Teknik Pengumpulan Data}

Untuk memperoleh data yang akurat tentang tari Dengka Pada dalam upacara Je'ne-Je'ne Sappara, maka teknik pengumpulan data yang digunakan adalah sebagai berikut:

a. Studi Pustaka; teknik ini digunakan untuk memperoleh data sekunder, yaitu data tambahan melalui sumber-sumber tertulis.

b. Observasi; teknik ini dilakukan untuk mengadakan pengamatan secara langsung terhadap tari Dengka Pada dalam upacara Je'ne-Je'ne Sappara. Teknik pengumpulan data ini didukung dengan alat dokumentasi: foto-foto data.

c. Wawancara; wawancara akan dilakukan dalam bentuk wawancara mendalam dengan pencipta tari Dengka Pada dan Ketua Adat.

d. Audio Visual; menggunakan alat rekaman seperti: kamera dan handycam.

\section{Teknik Analisis Data}

a. Reduksi Data. Interaksi analisis yang digunakan mengacu pada Miles dan Huberman (1994: 10-11), yaitu reduksi data, penyajian data, dan penarikan kesimpulan.

Dilakukan tahapan klasifikasi dan identifikasi data untuk mendapatkan data yang akurat. Setelah semua terkumpul, maka data tersebut direduksi sesuai dengan jenis dan sifat data.

b. Validitas Data. Data yang diperoleh di lapangan studi selanjutnya diuji kemantapan, ketepatan, dan kebenarannya dengan validitas. Validitas dalam penelitian ini menggunakan triangulasi. 


\section{Hasil Penelitian dan Pembahasan}

\section{A. Pengertian Dengka Pada}

Dengka Pada pada awal mulanya merupakan pengembangan dari sebuah permainan rakyat yang dalam bahasa Makassar disebut sebagai Paddekko, yang artinya penumbuk yang dilakukan oleh orang dewasa dan anak-anak. Menurut Nyonya Emba Rajamuddin (wawancara tanggal 14 November 2014) terdapat beberapa permainan rakyat. Ada untuk dewasa yaitu: paddekko, pasempa, dan pamanca' sedangkan untuk anak-anak yaitu: a'gasing, a 'longga, a 'kaddaro, enggo' dan a'cokko-cokko-ang. Namun yang akan dibahas dalam penulisan ini adalah Paddekko. Paddekko terbagi dua yaitu: A'dengka Pada: dilakukan oleh gadis-gadis dengan fungsi utama sebagai hiburan; dan Dengka Oleng: dilakukan dengan menumbuk padi untuk dijadikan beras oleh rakyat biasa yang berfungsi sebagai hajatan suatu pesta.

Tari Dengka Pada merupakan suatu peristiwa yang secara turun-temurun dilakukan oleh masyarakat Balangloe. Menurut narasumber Nyonya Emba Rajauddin bahwa: "Dengka Pada tidak dapat diketahui secara tertulis tetapi hanya diketahui melalui cerita-cerita para leluhur berhubungan dengan kepercayaan primitif yang timbul dari usaha manusia untuk menjelaskan dunia dan alam sekitarnya".

Hasil wawancara di atas dapat diketahui bahwa pada dasarnya aktivitas yang dilakukan oleh masyarakat Balangloe dalam upacara adat Je'ne-Je'ne Sappara adalah merupakan kebutuhan hidupnya, dan kenyataan seperti inilah yang selalu dihubungkan dengan upacara adat yang sakral.

\section{B. Fungsi tari Dengka Pada dalam Upacara Adat Je'ne-Je'ne Sappara di Desa Balangloe Kecamatan Taroang Kabupaten Jeneponto.}

Keberadaan lahirnya tari Dengka Pada tidak diketahui secara tertulis, hanya dapat diketahui lewat cerita leluhur yang bersifat mitos. Menurut narasumber bahwa tari Dengka Pada muncul pada saat masyarakat masih menganut kepercayaan animisme atau percaya kepada dewata.

Tari Dengka Pada muncul pada waktu panen masyarakat Jeneponto mengalami kerusakan, namun pada tahun berikutnya saat petani berhasil menuai padinya masyarakat bernazar, untuk membuat suatu upacara Je'ne-je'ne Sappara, tanpa sepengetahuan siapa pun muncullah seseorang yang tidak dikenal yaitu Tomanurung yang konon katanya berasal dari langit, membuat irama variasi dengan gerakan tarian.

Pada awalnya $P a$ 'deko Dengka Pada mulai muncul dalam gerakan yang sederhana. Namun dalam perkembangan selanjutnya, tari Dengka Pada mengalami perubahan menjadi tarian yang rutin dilaksanakan setiap musim panen selesai, sebagai rasa syukur kepada Tuhan Yang Maha Kuasa atas nikmat yang diberikan berupa keberhasilan panen yang melimpah.

Berdasarkan kenyataan di atas, maka dapat diketahui fungsi dari tari Dengka Pada dalam upacara Je'ne-Je'ne Sappara di Desa Balangloe Kecamatan Taroang adalah sebagai berikut: 
1. Berfungsi sebagai upacara pengucapan syukur di mana tarian ini dilakukan oleh gadisgadis cantik pada saat panen selesai sebagai tanda ucapan syukur terhadap Tuhan Yang Maha Esa atas berkat yang diberikan sehingga panen mereka bisa berhasil.

2. Berfungsi sebagai seni pertunjukan yang bersifat hiburan, bagi rakyat sebagai tanda bahwa mereka telah berhasil dalam menuai padi.

\section{Bentuk Penyajian Tari Dengka Pada dalam Upacara Je'ne-Je'ne Sappara di Desa Balangloe Kecamatan Taroan Kabupaten Jeneponto.}

Bentuk penyajian dan elemen-elemen komposisi tari Dengka Pada terdiri dari penari, ragam gerak, desain lantai, iringan atau musik, tata rias, busana atau kostum, yang diuraikan sebagai berikut:

\section{Penari}

Penari Dengka Pada berjumlah dua belas orang gadis-gadis cantik yang terdiri dari penari penumbuk sebanyak empat orang, yaitu untuk menumbuk gabah menjadi beras, penari Padu'duk yaitu: Padu'duk samping kiri sebanyak dua orang dan Padu'duk samping kanan sebanyak dua orang, penari Patapi sebanyak 4 orang. Penari penumbuk gabah menjadi beras empat orang, pemain pria Pamanca (pencak silat) satu orang yang didukung oleh sekelompok pemain musik yang biasanya terdiri dari tujuh orang pria dewasa.

\section{Gerak atau Ragam Tari}

Gerakan tari Dengka Pada ringan dan santai tanpa ketegangan otot. Sikap tubuh pemain selama menari senantiasa vertikal ke atas, torso tidak tegak juga otot perut tidak ditegangkan, hanya badan agak membungkuk melihat ke arah padi yang ditumbuk.

Gerakan tubuh hanya merupakan akibat dari gerak bagian tubuh lain yaitu: lengan bawah, lengan atas, dan tangan yang memegang alu.

Posisi kaki penari tertutup dan kedua kaki senantiasa digunakan sebagai tumpuan. Tidak ada angkatan kaki. Kedua kaki harus selalu tetap melekat di tanah, meskipun berat tubuh berada di kedua kaki, namun konsentrasi pemain tidak pada kaki melainkan pada bagian atas badan, karena gerak lengan dan tangan yang silih berganti bergerak.

Adapun bentuk atau ragam tari Dengka Pada adalah sebagai berikut:

a) Ragam pertama: Padengka Pada, penari penumbuk berjalan sejajar memasuki arena pertunjukan dengan gerakan tangan diayun ke depan dan ke belakang, sementara tangan kiri menjepit sarung. Para penari berhadapan di depan lesung, selanjutnya penari mengambil alu (alat penumbuk) yang sudah tersedia di lesung untuk menumbuk gabah.

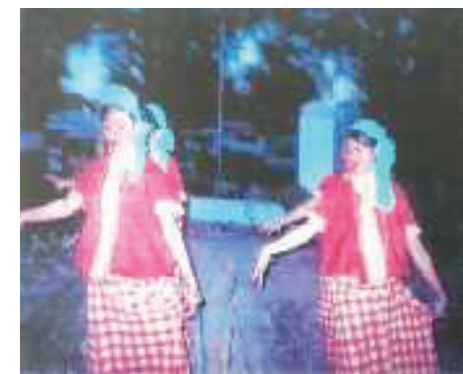

Foto 1: Ragam Pertama Penari Padengka Pada dengan posisi berbaris dua ke depan sambil tangan diayunkan.

Dokumentasi: Syamsiarni Nappu, 2007

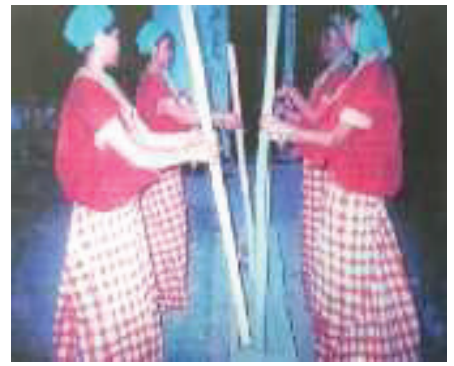

Foto 2: Ragam Pertama Penari Padengka Pada dengan posisi berhadapan dengan gerakan menumbuk padi.

Dokumentasi: Syamsiarni Nappu, 2007 
b) Ragam kedua: Padu'duk, penari padu'duk memasuki arena menuju ke penumbuk gabah untuk memberi semangat si penumbuk gabah.

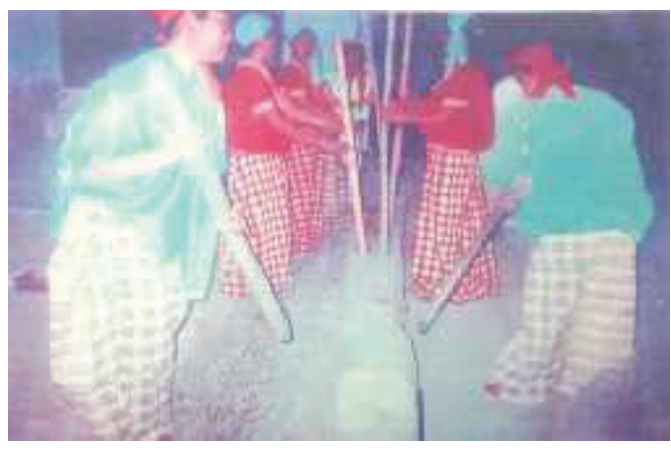

Foto 3: Ragam Kedua Penari Padu'du sudah bergabung dengan penari Dengka Pada. Dokumentasi: Syamsiarni Nappu, 2007

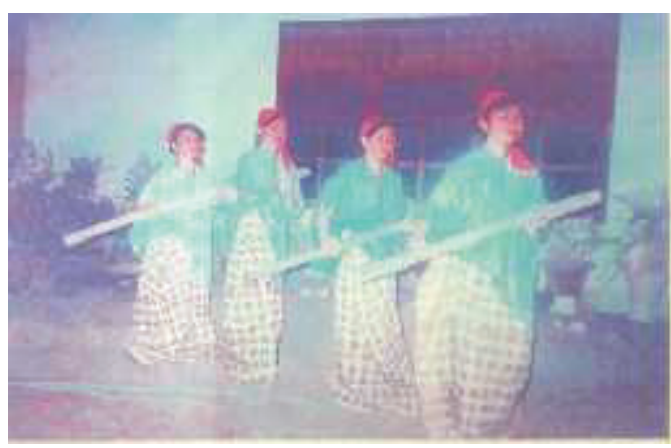

Foto 4: Ragam Kedua Penari Padu'du menuju ke penari Dengka Pada atau penumbuk padi.

Dokumentasi: Syamsiarni Nappu, 2007

c) Ragam ketiga: penari memasuki arena menuju ke penari penumbuk dan penari padu'duk untuk membersihkan gabah yang telah ditumbuk dengan membawa Patapi (alat pembersih beras).

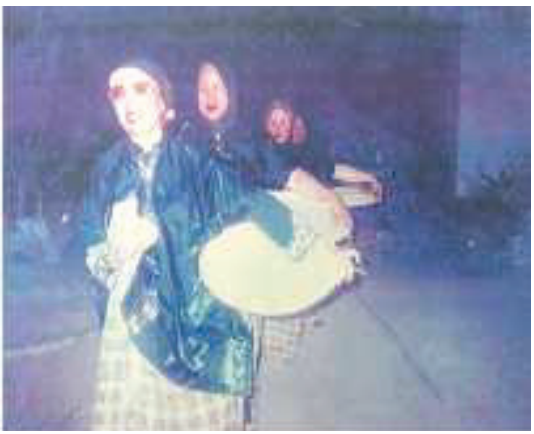

Foto 5: Ragam Ketiga Penari Patapi masuk arena pertunjukan

Dokumentasi: Syamsiarni Nappu, 2007

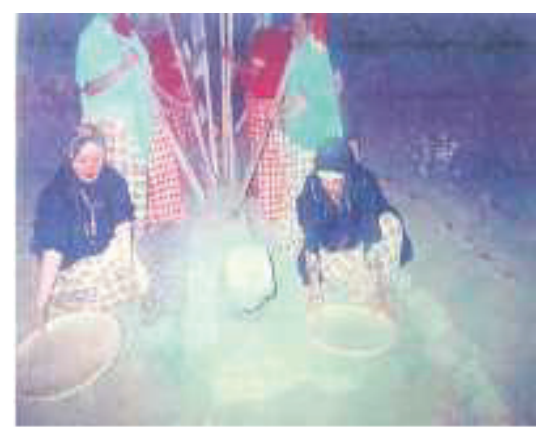

Foto 6: Ragam Ketiga Penari Patapi sudah membersihkan gabah yang sudah ditumbuk. Dokumentasi: Syamsiarni Nappu, 2007

d) Ragam keempat: penari pria memasuki arena sambil bergabung dengan para penari putri dan bersama-sama berputar dalam bentuk lingkaran. Pemain musik juga ikut bergabung bersama-sama dengan para penari dalam arena pertunjukan.

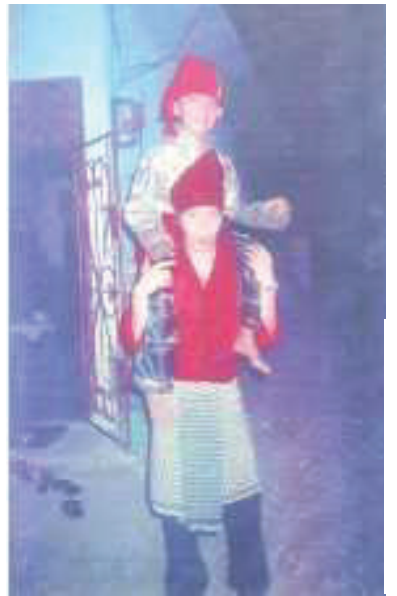

Foto 7: Ragam Keempat Seorang Penari Pamanca Disompo (duduk di atas bahu penari lain).

Dokumentasi:

Syamsiarni Nappu, 2007 


\section{Properti}

Properti yang digunakan dalam tari Dengka Pada sangat sederhana dan tidak terlalu memerlukan biaya yang banyak. Pada dasarnya properti yang dibutuhkan untuk permainan ini berupa assung (lesung) yang terbuat dari kayu (batang pohon). Ukuran panjang assung (lesung) lebih 2 meter dan lebar lebih $40 \mathrm{~cm}$ yang pada bagian tengahnya diberi lubang sebagai tempat menumbuk padi. Bentuk assung (lesung) ini menyerupai sebuah perahu lepa-lepa sedangkan alu (alat penumbuk padi), terbuat dari kayu atau bambu dengan ukuran panjang kurang lebih $120 \mathrm{~cm}$, dan nyiru atau pattapi (sebagai alat pembersih beras atau gabah).

\section{Pola Lantai}

Menciptakan bentuk gerak yang berkualitas pada tari Denka Pada diperlukan penanganan yang sungguh-sungguh dan sikap yang kreatif dalam mengolah pola lantai. Berdasarkan observasi penulis selama penelitian, pola lantai pada tari Dengka Pada sangat sederhana, karena hanya menggunakan satu macam pola lantai. Pemain tidak berpindah tempat, hanya berhadap-hadapan di kedua sisi assung (lesung). Para pemain berdiri di depan assung (lesung) sesuai dengan keinginannya sendiri dan berada di sisi samping panggung di depan kelompok pemain musik.

Pola lantai pada Tari Dengka Pada dapat dilihat pada uraian berikut ini.

\begin{tabular}{|l|l|l|}
\hline No & Pola lantai & \multicolumn{1}{c|}{ Uraian Gerak } \\
\hline & & $\begin{array}{l}\text { Ragam I } \\
\text { Penari Padengka berjalan masuk } \\
\text { mengambil alu (penumbuk) di lesung } \\
\text { untuk menumbuk padi. }\end{array}$ \\
\hline
\end{tabular}




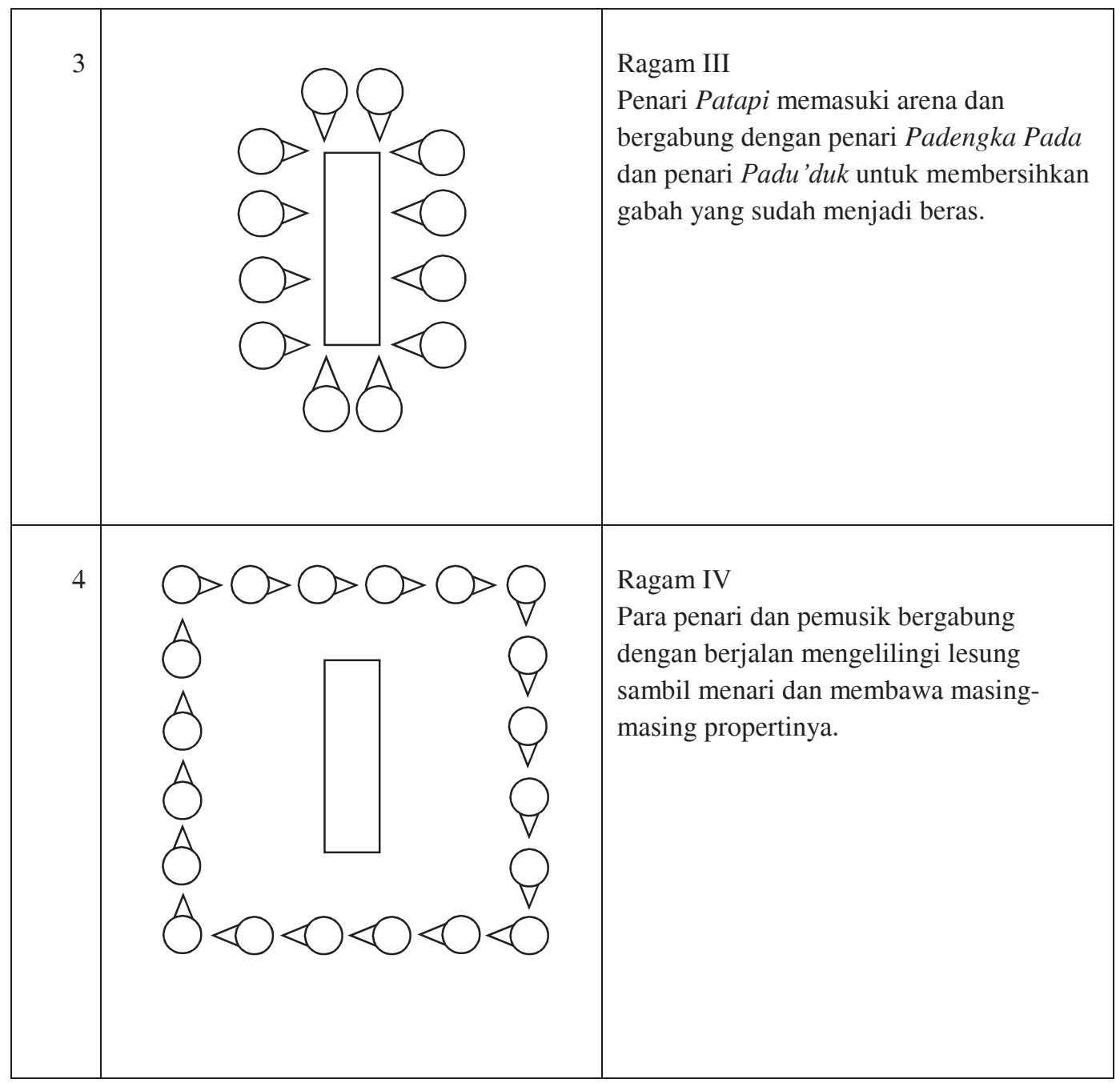

Keterangan: $\bigcirc=$ Penari

$$
=\text { Lesung }
$$

\section{Tata Busana/Tata Rias}

Busana yang dipakai dalam tari Dengka Pada sangat sederhana, yaitu berupa baju bodo dengan lipa sabbe (sarung sutra) dan dilengkapi dengan penutup kepala berupa selendang. Sarung sutra yang umum digunakan oleh penari Dengka Pada adalah cura 'labba, yaitu corak kotak-kotak besar. Menurut narasumber, kostum tari Denka Pada pada masa lampau menggunakan baju bodo dengan perhiasan berupa kalung panjang dan gelang yang terbuat dari emas tiruan.

Sedangkan kostum oleh pamanca dan pemain musik adalah berupa baju balla dada dan lipa sabbe serta menggunakan destar yaitu sejenis penutup kepala yang biasanya secara khusus dipergunakan para lelaki Jeneponto untuk mengikuti upacara tradisional atau pesta adat. 
Adapun warna kostum yang dipakai penari Dengka Pada adalah:

a) Baju bodo warna oranye, hijau, dan hitam untuk wanita.

b) Sarung cura'labba mengikuti warna baju untuk wanita.

c) Baju balla dada warna merah untuk pria.

d) Baju balla dada warna hijau untuk pria.

Tata rias yang digunakan dalam tari Dengka Pada sangat sederhana karena hanya memakai selendang di kepala sebagai hiasan.

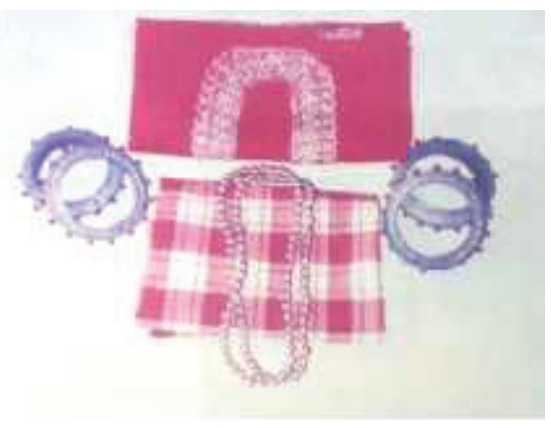

Foto 8: Kostum Penari Padengka Pada Dokumentasi: Syamsiarni Nappu, 2007

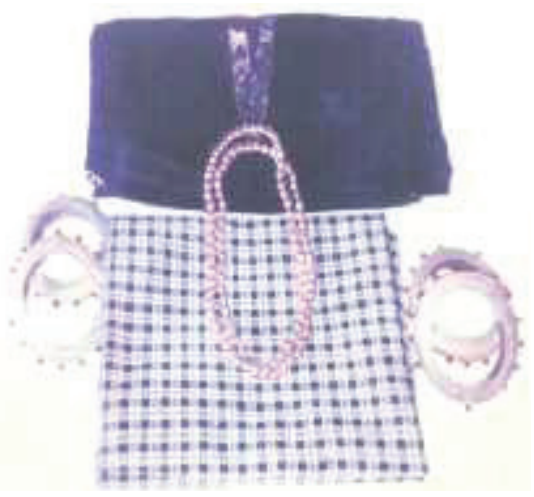

Foto 10: Kostum Penari Patapi Dokumentasi: Syamsiarni Nappu, 2007

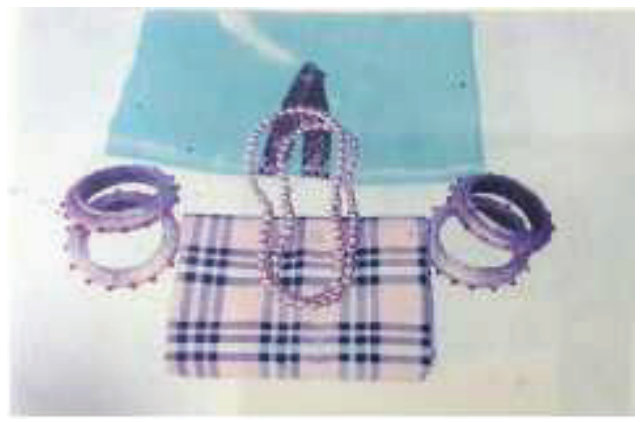

Foto 9: Kostum Penari Padu'du Dokumentasi: Syamsiarni Nappu, 2007

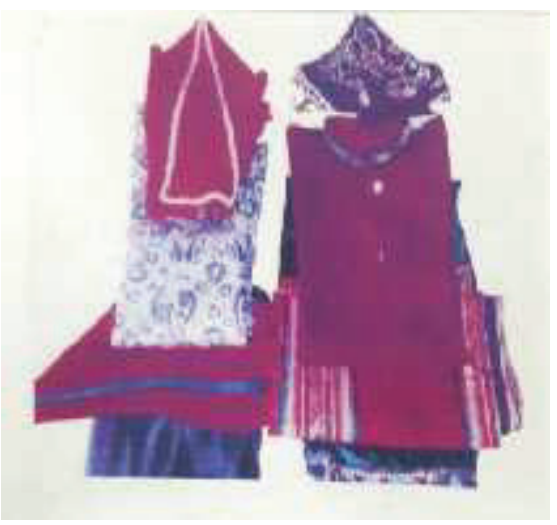

Foto 11: Kostum Penari Pamanca dan Kostum Pemain Musik

Dokumentasi: Syamsiarni Nappu, 2007

\section{Iringan Tari}

Musik yang mengiringi tari Dengka Pada adalah sebagai berikut:

a) Gong, terbuat dari bahan logam yang berpencu. Ketika ditabuh gong digantung, dimainkan oleh seorang pemusik dengan posisi duduk bersila.

b) Gendang, terbuat dari kayu berongan berbentuk silinder, bagian gendang ditutup dengan kulit kambing atau kulit sapi. Setiap gendang mempunyai dua sanrangan yang lebih besar disebut ulu sanrangan dan yang kecil disebut paja ganrang. Sebagai penguat, kulit tersebut diikat dengan rotan yang halus, di mana pada ikatan rotan di badan gendang diselipkan siame' yaitu selembar plat seng yang dipukul dengan alat pemukul gendang.

c) Rebana, bentuknya seperti silinder kecil yang direntangkan dengan kulit kambing dan kulit sapi, pinggirannya terbuat dari kayu. 
d) Pui-Pui, adalah musik tiup yang digunakan untuk memeriahkan acara pertunjukan.

e) Mandoliong, bentuknya menyerupai piano dengan ukuran panjang $50 \mathrm{~cm}$ dan lebar $15 \mathrm{~cm}$ yang terbuat dari kayu dan baja.

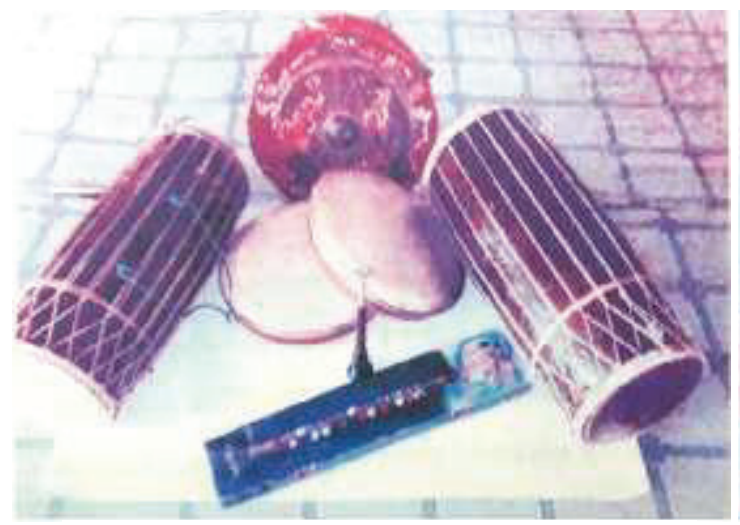

Foto 12: Alat Musik Tari Dengka Pada Dokumentasi: Syamsiarni Nappu, 2007

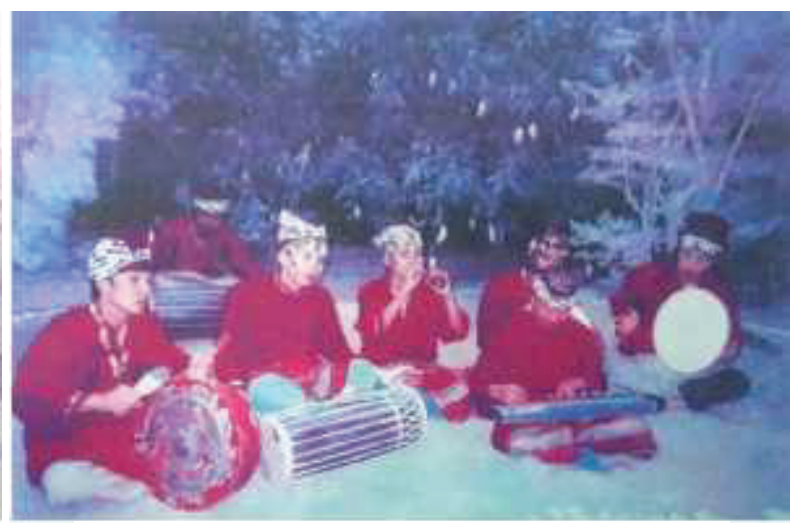

Foto 13: Pemain Musik Tari Dengka Pada Dokumentasi: Syamsiarni Nappu, 2007

\section{Kesimpulan}

Tari Dengka Pada merupakan sebuah tari tradisional masyarakat Sulawesi Selatan yang biasa ditampilkan dalam upacara Je'ne-Je'ne Sappara. Tari ini bagi masyarakat Jeneponto diperkirakan ada ketika masyarakat masih menganut kepercayaan animisme. Pada masa itu panen masyarakat mengalami kerusakan, maka masyarakat bernazar akan mengadakan upacara panen bila panen kelak berhasil dan ternyata betul. Masyarakat diberi rezeki berupa hasil panen yang melimpah, maka mulai saat itu masyarakat membuat upacara panen dengan memperdengarkan irama berupa alunan bunyi yang dihasilkan oleh tumbukan alu (alat penumbuk) ke dalam lesung (assung).

Tari Dengka Pada menggambarkan suatu kegembiraan di mana masyarakat Jeneponto yang telah berhasil dalam melakukan panen di sawah. Kegembiraan ini diwujudkan dalam gerakan tari, baik gerakan tangan dan kaki serta posisi penari pada saat berhadapan maupun dalam bentuk lingkaran. Pelaksanaan tari Dengka Pada ini dilakukan pada siang maupun malam hari di tempat keramaian seperti lapangan.

Tari Dengka Pada ini berkembang secara turun-temurun di lingkungan masyarakat Sulawesi Selatan khususnya masyarakat Jeneponto dan masyarakat pendukungnya.

Berdasarkan hasil penelitian yang telah diuraikan, maka dapat disimpulkan: fungsi tari Dengka Pada dalam upacara adat Je'ne-Je'ne Sapapara yaitu sebagai upacara pengucapan syukur atas keberhasilan hasil panen dan juga sebagai tari hiburan rakyat. Bentuk penyajian tari Dengka Pada dapat dilihat baik dari penari, gerakan tari, properti, pola lantai, busana atau kostum, iringan tari, dan tata rias. Tarian ini pada masa sekarang tidak lagi ditampilkan pada upacara pengucapan syukur yang sakral, tetapi merupakan bentuk penyajian seni pertunjukan yang bersifat hiburan kepada masyarakat. 


\section{Kepustakaan}

Kadir, Abdul. 1984. Inventarisasi Kebudayaan Daerah. Lephas Unhas.

Kayam, Umar. 1981. Seni Tradisional Masyarakat. Jakarta: Sinar Harapan.

Kussudiarjo, Bagong. 1984. Pendidikan Seni Tari. Bandung. Angkasa.

Latief, Halilintar. 1996. Kumpulan Sinopsis Warisan Tari Tradisional Sulawesi Selatan. Ujung Pandang.

Mery, La. 1986. Elemen-Elemen Komposisi Tari. Yogyakarta: LP3ES.

Mushar, Muhammad. 1998. Pengantar Adat dan Hukum Indonesia. Jakarta: Rajawali Press.

Najamuddin, Munasiah. 1983. Tari Tradisional Sulawesi Selatan. Ujung Pandang: Bakti Berita Utama.

Rendra. 1994. Upacara Tradisional di Indonesia. Jakarta: Gramedia.

Rusdiana, Lyas. 1982. Pendidikan Seni Tari untuk SMA. Bandung: Angkasa.

Santoso, Budi. 1982. Kesenian dan Nilai-nilai Budaya. Jakarta: P dan K.

Soedarsono. 1996. Tari-tarian Indonesia. Jakarta: P dan K.

Soejobrongto. 1990. Nilai-nilai Tradisional Nusantara. Jakarta: LP3ES.

Syahrir, Nurlina. 1999. Perkembangan Kesenian Sulawesi Selatan. Ujung Pandang: Percetakan Inti Sari.

Wiguyodipuro, Suroyo. 1994. Asas-asas tentang Hukum Adat. Jakarta: Djambatan. Wardana, Wisnu. 1990. Pendidikan Seni Tari. Jakarta: P dan K.

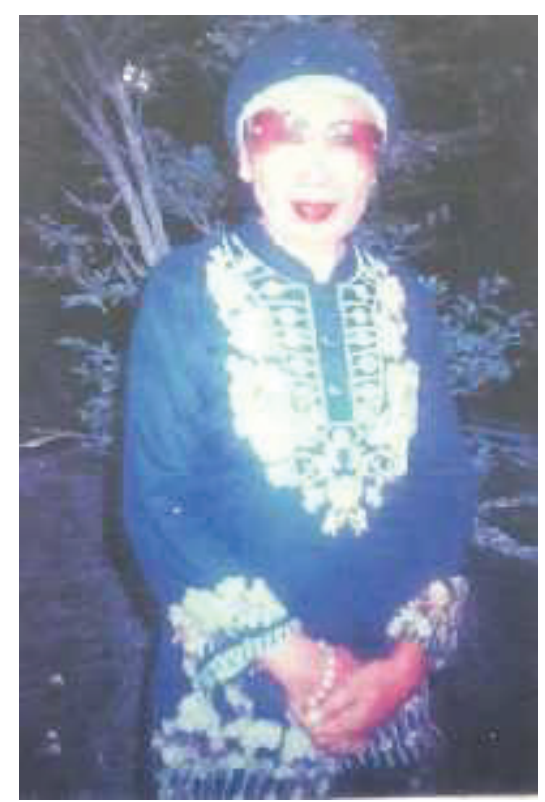

Foto Narasumber Tari Dengka

Pada, Emba Rajamuddin.

Dokumentasi: Syamsiarni

Nappu, 2007 